\title{
The role of ideology in politics and society
}

We attempt here to clarify ideas about ideology - what it is, how it is transmitted, how useful it is in making sense of society. We also examine its relevance to recent modern history both in Britain and in other parts of the world. Then we analyse the situation in contemporary Britain and consider whether it can be reasonably asserted that there is an ideological consensus in Britain or whether we are now 'beyond ideology'.

\section{POINTS TO CONSIDER}

Do ideologies help or hinder us in our understanding of society?

- Is there any sense in which ideologies (or any specific ideology) are 'true'?

> How might one distinguish between 'dominant ideologies' and 'ideologies of resistance', and also between 'restrictive' and 'relaxed' ideologies?

> Are the terms 'left' 'right', and 'centre' still useful ways of categorising ideological positions?

- What do some writers mean by the 'end of ideology'?

- British political parties nowadays often claim to be 'non-ideological' - are they right to do so? 
Our lives may be more boring than those who lived in apocalyptic times, but being bored is greatly preferable to being prematurely dead because of some ideological fantasy. (Michael Burleigh, The Third Reich: A New History, 2000)

We are now again in an epoch of wars of religion, but a religion is now called an 'ideology'. (Bertrand Russell, 'Philosophy and Politics', Unpopular Essays, 1950)

Ideology is . . . a system of definite views, ideas, conceptions, and notions adhered to by some class or political party. [Ideology] is always a reflection of the economic system predominant at any given time. (Soviet Philosophical Dictionary, 1954)

Political debate is widespread in society. Whether we are aware of it or not, most of us are, at a very simple level, political philosophers. In democratic societies like the UK and the USA citizens are expected to have opinions on a wide range of issues that either directly as individuals or collectively as citizens affect their lives.

Even at a simple, unsophisticated level we have views on the 'correct' form of government, freedom, equality and equal rights, the 'proper' role of government in society, how 'democratic' one's own political system is, the right levels of public spending, and so on. How we think about these and many other subjects will be influenced by the kinds of ideological beliefs we carry around in our heads, the product of our social conditioning, our life experiences and our reflections on them, the nation we live in, our educational level and our social class.

We regularly draw on this store of ideological beliefs when we try to make sense of the world. They may not be logical, well structured or even consistent (tortured are those who try to force their experiences into an ideological straitjacket; and, given enough power, they will often similarly torture others into wearing the same garment), but one's opinions and actions will make reference to those beliefs. Ideologies can be seen as a form of intellectual 'map' to help us find our way about the world, understand our place in it, analyse the political and social events going on around us. Maps vary in their degree of accuracy. One can assess their value by comparison with objective reality and debate with others.

Ideologies are associated with power structures. Politicians seek power. Their ideology and the social, economic and political circumstances of the time influence what they do with that power when they have achieved it. Indeed, it is impossible to separate the two. This applies even to those who deny having an ideology. The use of power always takes place in a framework of ideology. Modern politics can only be properly understood by reference to the great ideological movements: conservatism, liberalism, socialism, fascism, and so on.

Ideologies tend to have a bad press. They are often dismissed as 'errors' or 'untruths'. If ideology is 'a window on the world' it is a window with glass 
that distorts the vision. The viewer has difficulty thinking beyond these distortions and assumes what he or she believes to be the 'truth'. Ideology often distorts 'reality' and encourages conflict: 'One man's ideology is another man's falsehood.' Nevertheless, one must not fall into the trap of assuming that all ideologies are of equal validity. They should be respected as important ways of understanding the world. One should also attempt to examine one's own ideological beliefs, to better understand the role of ideology in politics and society.

\section{The meaning of the term 'ideology'}

So, given that ideology is very important in politics, what is 'ideology'? Is there something about ideological thought that is distinct from other forms of thinking? David Joravsky provides a useful starting point:

When we call a belief ideological, we are saying at least three things about it: although it is unverified or unverifiable, it is accepted as verified by a particular group, because it performs social functions for that group. ${ }^{1}$

In other words, holders of beliefs do not need to have had them 'proved' by some rational, scientific form of testing. To the believers they are the 'truth', the 'reality'. All political ideologies claim 'true' definitions of liberty, equality, justice, rights and the 'best' society. The 'particular group' mentioned above might be any social group: class, nation, profession, religious organisation, party or pressure group. All will have sets of ideological assumptions that are unquestioningly accepted as 'proper'. The 'social functions' ideologies perform are numerous. They will include the creation of a sense of group solidarity and cohesion for members of that group through shared ideological values; an explanation of the past, an analysis of the present, and, usually, a vision of the future with some description of how a better future will come about.

There has always been a widely held view in politics and political philosophy that 'ideology' merely provides a cloak for the struggle for power, the real stuff of politics. To justify their power and to persuade the people to obey, follow and support them, rulers use ideologies of various kinds. Machiavelli advised, in The Prince (1513), that religion was a very useful tool for the ruler. To Machiavelli the real objective of politics was the getting and keeping of power. Appeals to the welfare of the people were merely part of what we would call the ideological window-dressing, hiding the raw struggle for power.

Machiavelli put his finger on one of the most important roles of ideological belief systems (if we may include religion as one of these, for the moment). Until the last couple of centuries, in most societies the dominant form of belief was religion. During the seventeenth and eighteenth centuries rational and scientific forms of thought provided a growing challenge to religion. By the eighteenth century there were sharp and bitter tensions between religious and 
secular attitudes. One of the features of the Enlightenment was a strong, rational critique of religious beliefs and the perceived baleful influence of religion on politics. It was hoped that one could use reason to discover the laws governing the organisation and functioning of society as the laws of science were being used to discover the workings of nature. Once religion and other forms of irrational thought were removed from political discourse, it was believed, rational programmes would enable human society to improve dramatically.

These 'rational' forms of thought contributed to the criticism of the ancien régime in France, the French Revolution, and the development of what we now call 'political ideologies' that dominated political debate in Europe and the world during the following two centuries. Far from introducing new forms of rationality into politics, ideological forms of thinking tended to create new forms of 'irrational' thinking, stirring up and releasing deep political passions that in many ways resembled the emotional commitment to religion. Indeed, political ideologies for many became 'pseudo-religious' belief systems that had

ancien régime

The political and social order that existed in France before the Revolution of 1789 many of the hallmarks of religious commitment:

'heretics' were persecuted, 'true' interpretations of the creed formulated, ideological 'prophets' identified and definitive texts written to direct the 'faithful' into 'correct' ways of thought.

\section{Marxism and economic/class factors}

By the middle years of the nineteenth century industrialisation was transforming the economies, societies and the belief systems of the Western world. A new way of thinking about society was required. Many writers at the time contributed to the development of what came to be called a science of society: 'sociology'. The most influential were Karl Marx and Friedrich Engels, who had a striking influence on the study of ideology. In fact, they claimed to have created a 'science' of ideology.

In their studies of early industrial society Marx and Engels, especially in The German Ideology (1846), argued that there was a close link between the material conditions of society, the ways in which wealth was produced (the 'substructure'), and the resultant class structure and belief systems (the 'superstructure'). As the economic system changed so would the ideological system that sustained it, as would the class system that arose from the economic 'relations of production' associated with it. Class interests, in their view, shape ideologies. Take liberalism, for example.

Liberalism is an ideology. It claims, like all ideologies, to be a universal set of 'true' values that are appropriate for all people in all societies, and not just in 
a liberal society. Marxists believe that this is not the case. They argue that liberalism is of considerable use as an ideological tool to protect and reinforce the class interests of the propertyowning classes (the 'bourgeoisie') and help them to exploit the working classes (the proletariat). Liberalism may make eminent sense to the bourgeoisie, Marxists argue, and it may even convince members of the proletariat, but it essentially serves the interests of the former and helps the exploitation of the latter.

As ideology is associated with class interests,

liberal society

A society characterised by

freedom of thought, expression and political activity.

\section{proletariat}

In Marxist terminology the

proletariat is the class that lives

by selling its labour for a wage.

Often, but not strictly

accurately, identified with the

working class.

once society has become a one-class society as a consequence of the inevitable 'proletarian revolution', these 'false' bourgeois ideologies will disappear.

It is worthwhile identifying the interests behind ideological statements of principle by politicians. There is much that is of value in the Marxist analysis of ideology, despite the failure of political systems that described themselves as 'Marxist', such as the Soviet Union. However, there was a tendency for Marx and Engels and their ideological descendants to claim that their analysis of society is the one most in line with objective reality - the 'truth'.

V. I. Lenin, the Russian revolutionary, refined this doctrine of ideology further. In What is to be Done? (1902) Lenin not only worked out a strategy for a revolutionary party but saw socialist ideology as the ideology of the proletariat, a tool which they could use in their struggle for power with the ruling classes. This is a key development in the study of ideology. Henceforth, all Marxist analysis of ideology would treat it as a tool of class interests, whether working-class or ruling-class. Thus the Soviet Union, created by Lenin and built around his revolutionary party, was governed by people using a socialist ideology as the justification for their rule. The 'exploitation of man by man' under capitalism was replaced by the 'exploitation of man by man' under Soviet socialism.

\section{'Dominant ideologies' and 'ideologies of resistance'}

One can understand that ideologies may be perceived as a tool used by dominant social groups to maintain and enhance their established power position in a struggle of ideas. Antonio Gramsci, in Selections from the Prison Notebooks (1921-35), stressed the important role of dominant, or 'hegemonic', ideologies in capitalist societies as the means by which the dominant capitalist classes maintain their rule. Dominant ideologies permeate all aspects of society, from popular culture to the education system, from religious institutions to sports. Such ideologies legitimise the political system 
and the established social system in the minds of the working classes and ensure that the 'slave is persuaded that he is free': 'The proletariat wear their chains willingly. Condemned to perceive reality through the conceptual spectacles of the ruling class they are unable to recognise the nature or extent of their own servitude. ${ }^{2}$

However, dominant ideologies do not have the field all to themselves. Social and political groups in subservient power positions do not always accept the legitimacy of the system in which they live. Ideologies of resistance, or 'counter-ideologies', develop to give purpose and meaning to the social and political struggles of those wishing to reform or overthrow a given social and political structure.

An ideology may shift from being a counter-ideology to a dominant ideology by means of political success: Lenin's Bolshevik Party, for example, took over the Russian state and created the Soviet Union. Or an ideology might be one of both domination and resistance. Nationalism, for example, can be used by dominant nations as 'imperialist nationalism' or by subject nations as 'anticolonial nationalism', the former to support their power, the latter to challenge the status quo.

\section{'Restrictive' and 'relaxed' ideologies}

It would be wrong to assume that, although ideological thinking forms a part of all our waking thoughts, the experience of it and degree or intensity of commitment to a set of ideological beliefs are the same for all people. One can make a distinction between what might be called 'restrictive' ideological thought and 'relaxed' ideological thought.

'Restrictive ideologies' are a tightly argued body of ideas that logically hang together in a well-constructed framework, as can be seen in the 'great texts' of the ideological traditions that have shaped modern political life. Liberalism, conservatism, socialism, Marxism, fascism and the other ideological traditions and movements all have a recognised body of literature expounding the main tenets of their ideological belief systems. So, for example, the writings of John Locke, Adam Smith, David Ricardo and John Stuart Mill have considerably influenced the development of liberalism. No study of conservatism in Britain would be complete without reference to the speeches and writings of Edmund Burke, in particular his Reflections of the Revolution in France (1790). Marxism, and its class analysis of capitalist society, is, of course, honoured by its eponymous core thinker and voluminous writer, Karl Marx. Hitler and Nazism, Stalin and Stalinism, Mao and Maoism. In all these cases it is impossible to think of the movement without also thinking of the ideological tracts that shaped its image along lines formulated by the leader. 
The term 'restrictive ideologies' conjures up the image of rigidity, narrowness and bigotry in the ideological cause. It does not necessarily describe some of the great texts associated with political movements. They provide a reference point for thought and action, a sense of identity with, and commitment to, the movement, and often demonstrate a degree of flexibility in practical use that enables ideologies to keep in touch with the world around us and so remain relevant to contemporary concerns. Indeed, democratic politicians sometimes clearly state their political programme in terms of a struggle of ideologies

Paradoxically unless we stake out our ideological boundaries and defend them against external assault and internal subversion we will not attract to our cause the millions of non-ideological supporters who are necessary for our victory. A clear statement of our philosophy is essential to our success and perhaps our survival as a major political force. ${ }^{3}$

However, all too often restrictive ideologies can become mere excuses for lack of rationality on the part of the ideologically committed. Ideology becomes a source of narrow-mindedness and unthinking conformity that crushes the originality of the individual adherent. The lives of millions can be oppressed, distorted or lost by political movements driven to impose an ideological 'truth' on their society.

'Relaxed ideologies', on the other hand, are sets of ideological assumptions shared by a social group. Such beliefs are often not clearly thought out or logical or coherent. They may be indirect and accidental connections of ideology and power. We are all creatures of ideology, even though our ideologies are not necessarily well thought out or logical. The holders of relaxed ideological beliefs may not even be aware that their opinions are ideological; they seem to be just 'common sense'.

\section{'Left', 'Right', and 'Centre'}

These terms are a common shorthand in discussions of politics - so common, in fact, that one often uses them without a real grasp of what they mean. The application of 'left' and 'right' to politics derives from the French Estates General (1789), chaired by King Louis XVI. Delegates were divided into aristocratic members, who sat at the right hand of the king, and the revolutionary and populist members, who sat to the left.

Those on the political right stress patriotism, order, social discipline, traditional values,

Estates General

The body which in pre-

Revolutionary France

represented the three 'Estates'

or legal and social

classifications. The First Estate

was the nobility, the Second the clergy, and the Third was the rest of society. suspicion of over-powerful governments, and freedom and individuality as a higher political 'good' than equality. The centre has somewhat different political values, involving less inequality, a greater 
role for the state in helping individuals, a greater stress on freedom, and optimism about the possibilities for improving human nature and society. To the left of the centre the emphasis on the role of the state in creating greater social equality grows, including collective ownership of the means of production, greater emphasis on class rights and a class analysis of society. One might imagine a political 'spectrum', a horizontal axis, with these ideas and principles shading into one another, rather than distinctive 'boxes' with sharp dividing lines between them on principles of social and economic policy.

Political scientists also identify a vertical axis of degrees of 'authoritarian' or 'democratic' inclinations of ideological supporters. Another vertical axis might be identified as leaning towards the 'status quo', or 'conservative', view of resisting change as compared with the 'revolutionary' or 'radical change' wings of an ideological movement.

In recent years the political 'spectrum' has been largely replaced as a conceptual tool by a 'political horseshoe', in which the far left and far right bend round to be so close as to have much in common in terms of authoritarianism and totalitarianism. It is relatively easy for some voters to shift their support from communist to fascist parties and vice versa.

The nature of modern domestic and international politics has raised questions about the continuing validity of the spectrum model of political values and ideologies, which originated in the nineteenth century, for the early twentyfirst century. Green politics, environmentalism, feminism, gay politics and animal rights, as well as religious politics, do not fit very easily into such a conceptual framework.

\section{The end of ideology?}

It might seem strange, given our view that ideological thought is a permanent feature of politics, to claim that ideology is in decline or even 'dead'. Yet several writers have argued this, most notably Daniel Bell and Francis Fukuyama.

Daniel Bell, in The End of Ideology (1960) and later in an article in Government and Opposition (1988), argued that ideological debate was in decline as a means of understanding society. Societies have changed so much that 'old ideological' forms of analysing those societies, especially Marxism, are virtually useless. Modern societies are concerned with non-ideological problem solving. They have become more moral, more liberal and only distantly connected with a class analysis of society. Bell's analysis was greatly influenced by the Cold War struggle and the need to show that Marxism was defunct both as a conceptual tool and for political action. 
Francis Fukuyama, in The End of History and the Last Man (1992), elaborated ideas he had previously published to argue that the end of the Cold War had shown the triumph of liberalism and liberal democracy to be the ideologies of modern scientific and technological societies. Liberal democracy was of universal application and represented the ultimate objective of mankind. Ideological conflicts arising out of feminism, nationalism, environmentalism and anti-racism are merely representations of the fundamental worth of liberal-democratic values. Indeed, they take place within a framework of liberal-democratic ideological assumptions.

Bell and Fukuyama and other 'end of ideology' writers have been very influential. But they have been attacked for being propagandists for American economic and political domination of the planet. They have also been attacked for having ideas that are in fact highly ideological in themselves and for systematically ignoring evidence that challenges their thesis. There are many peoples, such as those in the Islamic world, who adhere to ideological systems that do not assume that the 'American' way is best, or that liberal democracy is the answer to their social and economic problems.

\section{The transmission of ideologies}

We have observed that ideologies arise out of particular social circumstances and reflect the structures of power in society. An ideology, however, is customarily presented as a natural and rational analysis of society. It will carry with it the assumption, overt or covert, that opposing ideologies are somehow unnatural and irrational. Ideologies claim they are universally applicable to all peoples in all societies and are not the product of a particular time and place. They create a particular language of meaning and explanation to encourage the individual to develop a sense of being a full member of a major movement for social reform. Certain words and images will act as 'triggers' to stimulate a chain of ideas associated with a particular ideology, to encourage solidarity among its supporters and stress the divisions among the supporters of counterideologies. As part of this, criticism of the ideology will be associated with negativity and can be dismissed as such by its supporters.

These points may give the impression that one is talking about the restrictive ideological forms of ideology, but they also apply to the relaxed forms of ideology in society. A study of newspapers, television programmes and advertisements reveals many subtle, and not so subtle, conscious or unconscious, 'tricks' of the ideological transmission trade.

Ideological assumptions thus affect all aspects of society: family, political parties and pressure groups, local and national politics, and international politics. One must not, however, think that ideologies emerge as part of a 
conspiracy by a Machiavellian elite to brainwash the public. This would be far too simplistic a view of how ideology develops. Members of the elite in any society rise from that society and generally share the ideological and cultural values of most of its members. There is an ideological element to most aspects of culture. The elite themselves may not realise they are acting selfishly. They may genuinely believe that their views are in the interests of all in society. Marxists, however, would claim such a view of the elite's awareness of their interests and ideology to be naive.

There are many vehicles by which ideological values are transmitted to society: they include family, work, friends, the mass media, political parties and other political and social institutions. The family plays a crucial role in the socialisation of new citizens into the ideological values of their society. There are power relations between men and women, parents and children, all of whom are influenced by ideological concepts, often unthinkingly acted upon by the members of that family. A child's first experiences of power in society and the ideological values it acquires occur, almost literally, with their mother's milk in the context of the family.

Families have an enormous effect on the life chances of their members. Especially important are their occupational and social-class positions, which will play a major role in influencing the educational level of the children, their future occupations, their religious and moral values and their choice of friends. All of these factors will have ideological messages that influence the political values of the individuals concerned. Most such ideological values will be of the relaxed kind, but some people will seek a more restrictive ideological expression of their political views and will join a political party.

Political parties are clearly ideological vehicles, designed to fight elections by appealing to the electorate with a manifesto containing policy proposals that are shaped by ideological values. They must appeal to the electorate with some resonance with the electorate's own ideological values, garnering enough support to win seats in parliament and, possibly, control of the local or national government. Appointments to cabinet posts by, say, the British prime minister, will be made with reference to a range of factors, which will include experience, competence, intelligence, loyalty; but one of the most important will be ideological compatibility and conformity with the prime minister's outlook and the broad ideological and policy aims and objectives of the party.

\section{The importance of ideology in modern history}

By now the importance of ideologies in political discourse should be clear. But if there are any lingering doubts, the importance of ideology can be observed in the shaping of world history. 
The musings of thinkers have ideological content which, in a myriad of direct and indirect ways, influences the thoughts, policies and actions of politicians and people alike. There is not some 'real' world where people act in a pragmatic manner. We can only understand the world by reference to ideological points of view, while at the same time being aware of the limitations and distortions of our own deeply held ideological beliefs. One can, therefore, gain some idea of the importance of this key link between ideology, thinkers, power and society by studying examples from history.

Ideological debate was an important feature of political life before the twentieth century, but it has influenced politics during the twentieth century in ways that are different from previous times. To begin with, governments and politicians seek clear ideological justifications for their actions and consciously attempt to carry out policies in line with an ideological agenda. Next, modern communications technology ensures that ideological debate and competition is now global in scope. Furthermore, modern states buttress their power by manipulating public opinion along ideological lines by appealing to ideological principles shared by voters and rulers alike. Third, the role of genuine public opinion (formed as a result of people's own experiences) in influencing policy is reduced. Ideological 'spin doctors' manipulate public opinion to such an extent that there is little ideological debate that does not originate from within the political elites. Finally, sections of the intellectual classes in liberal societies adopt the ideological views and positions of extreme political parties and provide political and economic elites with powerful ideological tools for manipulation of the citizenry.

Political ideology now, more than ever before, is very closely linked to state power whatever the political system. The twentieth century, and one sees little hope that this will change in the twenty-first, was one in which ideological falsification, exaggeration and simplification held sway. Ideologies have often taken on the guise of 'political religions', pursuing some form of human perfection, the elimination of all social conflicts, and making claims of being the only vehicles for the 'truth'. It seems as if this form of ideological politics is a natural product of the mobilisation of millions of voters in a mass democracy.

If one accepts Eric Hobsbawm's thesis, in The Age of Uncertainty (1994), that the twentieth century makes historical coherence by being considered as lasting from 1914 to 1991, then it was dominated by ideological struggles for dominance among liberal democracy, fascism and communism.

Societies shaped by liberalism dominated the international system at the start of the twentieth century, although a strain of pessimism seemed to be in the ideological and intellectual air, despite a previous century of great economic, social, political, technological and cultural progress. A belief that the onward 
march of liberal civilisation would not last was a theme among many thinkers as 1900 dawned.

The First World War was a greater shock than people could possibly have imagined. It badly disrupted the global economic system that had been created by Britain in the nineteenth century and wrecked the liberal assumption of inevitable progress. During the two decades after 1918 pessimism deepened as liberalism appeared discredited and out-dated to millions of Europeans. Many therefore turned to fascism and communism, which they envisaged as offering youthful, optimistic and more effective ideologies of renewal and progress.

One could hardly say that ideology does not matter when one considers its impact on the domestic politics of Italy, Germany and the USSR under Mussolini, Hitler and Stalin, respectively. Fascism and communism contained the most extreme elements of ideology found among the many forms of twentieth-century ideological thought. Complex realities were simplified into one fundamental truth of a struggle of good and evil, right and wrong, with a chosen group based on class, race or belief leading the way to a better world. Political opponents, 'undesirable' racial groups and whole social classes were subject to stereotyping, oppression, incarceration and extermination in line with ideological considerations. Common also to both fascist and communist movements was the hatred and contempt for liberal values and parliamentary democracy, which supposedly betrayed the nation or the class.

The consequences for the international balance of power were very great. Nazi foreign policy was formed by an aggressive ideology of expansion. Western liberal democratic suspicions of communist Russia (suspicions that were reciprocated by Stalin) dogged attempts to create a united diplomatic front in the face of the Nazi threat and contributed to the slide into war in the late 1930s. The Nazi-Soviet Pact of August 1939 was shocking not only in terms of its strategic implications, but also in the breathtaking implausibility of two ideological enemies making a non-aggression treaty. Equally implausible was the alliance between liberal democracy and communism that arose during the war that followed.

The Second World War was an ideological struggle with several military dimensions. Fascism and Nazism fought a war against liberal democracies in the West, which their leaderships hoped could be ended by a negotiated peace, despite the Allied declared policy of 'unconditional surrender'. Nazism fought another war against Soviet communism in the East, a war in which there could be no ideological compromise, no end other than the total defeat of side or the other, a war of incredible levels of ferocity and brutality. Nazi ideology defined whole groups as 'sub-human' and the extermination of millions of Jews, Gypsies and Slavs followed. A third ideological conflict, that between the liberal West and Soviet communism, was suspended while Nazi Germany still 
posed a threat. But even before fighting in Europe had ended, the conflict that was to lead to the Cold War was well under way, with growing suspicion and hostility between the Anglo-Americans on one side of a divided Europe and the Soviets on the other.

The Cold War was the second great ideological struggle of the century. The planet divided into a bi-polar world of liberal-democratic nations under the leadership of the USA and a communist world under Soviet leadership. A 'Third World' between the two, neither communist nor capitalist, progressively became the battleground for the ideological and military conflicts of the Cold War. Only the possession of massive conventional forces and nuclear weapons by both the USA and the USSR prevented the deep ideological animosity between the two superpowers from erupting into war during the many crises that punctuated their struggle. By the mid-1980s the Cold War was coming to an end and the ideological conflict was winding down. However, nothing prepared the world for the dramatic end of the Soviet Union and the communist regimes in Eastern Europe between 1989 and 1991.

The post-Cold War world seemed to be one in which the ideological struggles of the previous seventy years had come to an end. Liberal democracy appeared triumphant, with the last of its totalitarian enemies gone. However, the end of communism did not mean the end of ideology. Virulent nationalism erupted in Yugoslavia, tearing the state apart, and again in Chechnya, Georgia and other parts of the former Soviet Union. Fascism began to march again in many of the previously communist nations of the East and gained new supporters in the West. Finally, as the new century dawned, virulent Islamic fundamentalism offered a massive challenge to the smug ideological assumptions of the West of a decade earlier.

Ideology was not dead. It had never been absent even in the supremely pragmatic politics of Britain.

\section{The role of ideology in British politics during the age of consensus}

It is often stated that the British are 'pragmatic' in their political and social arrangements and not greatly influenced by ideological considerations. Implied in this is an assumption, itself ideological (related to nationalism), that British politics is a superior way of doing things compared to the consciously ideological 'European' politics. Yet ideological values greatly influenced the development of British politics during the twentieth century, as one can see from a quick resumé of British political thought.

Adam Smith, in The Wealth of Nations (1776), and David Ricardo, in Principles of Political Economy (1817), have had great influence on the development of 
free-market economics in Britain during the last two hundred years. Liberal ideas about the minimal state and free trade as the best means towards economic growth and the generation of wealth owe much to their works. Indeed, it is impossible to follow an economic debate today without hearing people, often unconsciously, using the ideas of these long-dead liberal economists. John Locke, writing almost a century before Smith, expressed key liberal elements of the importance of property and individual conscience in economic and political discourse in his Two Treatises of Government (1690). John Stuart Mill, in On Liberty (1859), drew together widespread liberal beliefs of his day to create a powerful statement on behalf of individual freedom. Late nineteenthcentury New Liberals reinterpreted liberalism to encourage a greater role for the state in society so

consensus

A general agreement on basic principles, disagreement being confined to details. Government in Britain from 1945 to 1979 is often said to have been 'consensual' since most main parties accepted a mixed economy with a substantial public sector, welfare state provision and a measure of social equality as to enhance individual potential in ways that the minimal state would not do. These thinkers and their ideas have had a considerable influence on the development of the post-war consensus, and will no doubt continue to influence twenty-first century politics and economics.

The modern British political debate over the welfare state, the NHS, education, employment and taxation levels makes reference to ideological values. Modern Neo-Liberals (who make a strong case for a return to nineteenth-century classical liberalism) face an uphill battle against the dominance of social-democratic ideology in the debate. So strong is the ideological consensus, so deeply entrenched in the social and political values of modern Britain, that it is almost impossible for us to imagine life in a society without these values and the institutions created to bring them into existence.

This may be true in the case of the restrictive view of ideology. There is, apart from the political extremes, very little reference to liberalism, socialism, conservatism, and so on, in the debates that occur in British politics. Even at election time, so it is argued, there is little that might be called ideological, only a pragmatic reference to, for example, what level of taxes to pay for public services.

However, that is not the case with relaxed ideologies. Some writers, such as Samuel Beer, in Modern British Politics (1965) and Britain Against Itself (1982), and Peter Jenkins, Mrs Thatcher's Revolution (1987), have argued that British politics is very ideological; so ideological, in fact, that it has damaged the country's economic performance as incoming governments abruptly changed policies in line with their ideological commitments: nationalisation and privatisation, high taxes or low taxes, high public spending or spending cuts, and so on. 


\section{The post-war consensus and ideology}

Even if the arguments of Beer and Jenkins are not completely accepted there are grounds for claiming that British politics has been very ideological in the relaxed sense of the term, even if not in the restricted sense.

The post-war era since 1945 has been dominated by an ideological 'consensus', whatever the pragmatic claims made for it. Policy considerations, while acquiring the label 'pragmatic' or even 'common-sense', can be ideological in their underlying assumptions, in a sense that is associated with social democracy. From the wartime coalition government until the early 1980s all the major parties, both in and out of government, largely agreed on the basics of government policy. These included the following:

- a commitment to full employment by the use, if necessary, of Keynesian Demand Management techniques;

- the creation of a welfare state with extensive social benefits in terms of health (the NHS), pensions, childcare and benefits, unemployment and sickness payments and expanding educational opportunities;

- the encouragement of economic growth to ensure full employment and the means to pay for welfare state provision;

- a 'mixed economy' of state-owned ('nationalised') key industries, such as coal, steel, railways, working within an economy that largely remained in private hands;

- a 'corporatist' (sometimes called 'tri-partist') approach to economic planning that involved the co-operation of government, business and organised labour;

- the dissolution of the empire (largely completed within twenty years of 1945);

- a commitment in defence and foreign policy to the Atlantic Alliance with the USA, the acquisition and maintenance of a nuclear deterrence, and, from the late 1950s, closer political and economic links with the states of Western Europe.

There was often little difference between Labour and Conservative governments. Their pragmatism was based on the acceptance of similar policy goals in order to win elections. Yet this is clearly an example of ideology. It assumes a significant role for the state in the economy and society. There is a strong belief in state intervention to improve social and economic conditions, a belief based on a very clear set of ideological assumptions that can be identified as being 'centre-left' or 'social-democratic' in their orientation.

However, even during the high point of this consensus, from, say, 1945 to the early 1970s, there were those in both major parties who were

\section{pragmatism}

An approach to decision-making that is focused on desirable outcomes to solving social and economic problems, rather than ideological principles. 
opposed to the consensus policies of their respective leaderships. The left of the Labour Party wanted greater state intervention and control in society and the economy, while the right of the Conservative Party wanted a massive withdrawal of the state from any areas of social and economic activity and a significant reduction in the levels of taxation. They had little actual effect on the policies of their parties, as consensus politics appeared to be what the majority of the electorate wanted. Political debate and electoral competition revolved around who could manage the system best, who could deliver the greatest level of economic growth, public services and social improvement for least cost and effort.

This social-democratic consensus was successful in establishing an ideological grip on British politics for a number of reasons. The mass unemployment, poverty and failure of the 1930s discredited the minimal state policies of the governments of the day. The Second World War involved massive state intervention in the form of 'War Socialism' that led to victory. If such methods could defeat the Nazis why, it was widely demanded, should state planning not defeat poverty and unemployment afterwards? At last, the long economic boom of the 1950s and 1960s appeared to show that Keynesian economics worked and governments did not have to make difficult choices about state spending and private income levels. Economic growth would enable Britain to have both excellent public services and high individual standards of living.

\section{Challenges in the 1970s}

The 1970s challenged the post-war consensus. There were a number of reasons for this. The post-war economic boom came to an end with growing economic difficulties, especially rising inflation and unemployment. Economic decline became more obvious as mining, shipbuilding, steelmaking, textiles and heavy engineering went into apparently terminal decline. With that decline came the shrinking of trade-union membership. By the 1970s the postwar generation that grew up with the welfare state and social democracy were a majority of the electorate. At the same time economic prosperity was growing in the new service sector and white-collar areas of the economy. With that came a new individualism, a new impatience at the inefficient and collectivist provision of state-run services and industries.

In both the Labour and the Conservative parties the anti-consensus elements recognised their opportunities for power. The Labour Party moved to the left, thereby losing both members and a close connection with the Labour Government (1974-79). In 1981 it split over ideological issues, with many of its right wing going on to form the Social Democratic Party (before ending up after its demise a few years later in the Liberal Democrat Party). The Conservatives moved to the right, slowly at first, but gathering pace under the 
leadership of Mrs Thatcher after 1975. These ideological changes were of significance in the following decade. The Labour Party was condemned by voters as extreme, and it subsequently lost four elections in a row. The Conservative Party, in power (1979-97), was able to pursue policies that challenged many aspects of the post-war consensus.

\section{A new consensus?}

The Thatcher and Major governments attempted to create a new right-ofcentre ideological consensus for British politics, heavily influenced by neoliberalism, and to bring about a fundamental shift away from the socialdemocratic consensus. The features included the following:

The concept of the mixed economy was to be challenged by the transfer of state-owned industries to the private sector, a process known as 'privatisation'.

- Corporatism was to be rejected and the role for trade unions and business in formal government economic planning was to be ended.

There was a strong commitment to market economics as the best means of ensuring economic efficiency and high levels of economic growth.

- Keynesian economic management was to be abandoned, along with the commitment to maintaining full employment. Inflation was to be the major economic 'dragon' for the government to slay, by the adoption of free-market and 'monetarist' policies.

The welfare state was to be challenged with cuts in benefits and entitlements, the introduction of more means testing for claimants, and the introduction of market solutions into the health and education services.

The level of taxation on both individuals and businesses was to be steadily reduced as incentives for both to work harder, and take risks and succeed. There were clearly strong elements of liberalism at work here in the economic policies and in the stress on individualism and individual choice and effort. Conservatism raised the role of the family, traditional values, patriotism, discipline and hierarchy. It was even possible to see elements of Marxism in the emphasis on the role of economics in building society.

The new consensus can be recognised in the Labour Party's shift to a rightof-centre programme under Neil Kinnock, John Smith and, especially, Tony Blair. There was no significant reversal of Conservative policies after Labour came to power in 1997. Welfare spending was kept under tight control, helped by high levels of economic growth and low unemployment. Attacks were made on benefit fraudsters and the automatic nature of some benefits. There was considerable support for free-market capitalism, no return to corporatism and no great changes to the tough trade-union legislation of the 1980s. No 
nationalisation occurred, although Conservatives claimed that the end of RailTrack in 2001, during Labour's second term, was the thin end of the wedge leading to renationalisation. Even policies such as the minimum wage and family income-tax credits were designed to encourage people into work rather than rely on state benefits. Pragmatic policies, yes, but with ideological underpinnings familiar to the post-war consensus and its successor.

\section{Summary}

People have ideological beliefs, even if these beliefs are not very coherent. Ideological beliefs are beyond rational or scientific testing, whatever the claims of their proponents. Such beliefs perform a social role for those who hold them. Some critics argue that ideologies are simply instruments of power, wielded by the dominant groups in society. Another hostile opinion is that ideologies, especially 'restrictive' ones, mentally enslave those who believe in them. Some modern thinkers have argued that 'ideology is dead', that no one believes in any ideology, and that conflicts no longer have an ideological basis. Opponents of such views can point to abundant evidence that liberal capitalism is deeply influenced by ideology. Ideological beliefs were of profound influence in twentieth-century history. New forms of ideology, such as militant Islamism, seem likely to be important in the twenty-first century. While it may be true that ideology in the 'restrictive' sense is largely absent from British politics, this is certainly not the case with 'relaxed' ideology. From 1945 to 1979 there was a clear consensus between the major parties which constituted such an ideology. A consensus exists today, though it is far more influenced by neo-liberalism than was the case in the period before 1979 .

\section{REFERENCES AND FURTHER READING}

1 D. Joravsky, 'Soviet Ideology', Soviet Studies, 18 (1966).

2 J. Femia, Gramsci's Political Thought (Oxford University Press, 1981).

3 R. Hattersley, Choose Freedom (Michael Joseph, 1987).

Barry, N. 'Ideology', in P. Dunleavy et al., Developments in British

Politics 3 (Macmillan, 1990), pp. 17-41.

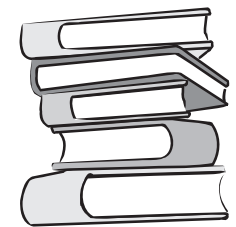

Dutton, D. British Politics Since 1945: The Rise and Fall of

Consensus (Blackwell, 1991).

Eagleton, T. Ideology: An Introduction (Verso, 1991).

Eatwell, R. 'Ideologies: Approaches and Trends', in R. Eatwell and A. Wright (eds.),

Contemporary Political Ideologies (Pinter, 1993), pp. 1-22.

Goodwin, B. 'Ideology', in B. Goodwin, Using Political Ideas (John Wiley and Sons, 2001), pp. 17-31.

Heywood, A. 'Introduction: Understanding Ideology', in A. Heywood, Political Ideologies: An Introduction (Macmillan, 1992), pp. 1-23. 
Leach, R. British Political Ideologies (Philip Allen, 1991).

MacKenzie, I. 'Introduction: The Arena of Ideology', in R. Eccleshall et al., Political Ideologies: An Introduction (Routledge, 1994), pp. 1-27.

McLellan, D. Ideology (Open University Press, 1986).

Plamenatz, J. Ideology (Macmillan, 1972).

Plant, R. 'The Resurgence of Ideology', in H. Drucker et al., Developments in British Politics (Macmillan, 1984), pp. 7-29.

Plant, R. 'Ideology', in H. Drucker et al., Developments in British Politics 2 (Macmillan, 1988), pp. 8-33.

Seliger, M. Ideology and Politics (Allen and Unwin, 1976).

Thomas, G. P. 'British Politics 1945 to Date: The Postwar Consensus', Taking Politics, 7:2 (1995), pp. 117-24.

Vincent, A. 'The Nature of Ideology', in A. Vincent, Modern Political Ideologies (Blackwell, 1996), pp. 1-21.

\section{SAMPLE QUESTIONS}

1 Are ideologies simply a cloak for the pursuit of power?

2 Are ideologies developed in the nineteenth and twentieth centuries of any value in the twenty-first?

3 'While ideology shaped the twentieth century, we have now come to the end of ideology.' Do you think this is true, and if so is it a

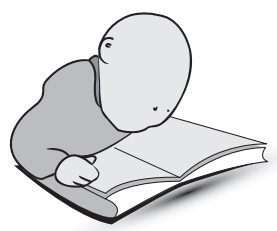
cause for rejoicing?

4 Why do you think 'ideological' is seen as such a term of abuse in modern Western democracies?

5 To what extent would you agree with the opinion that politics has become less ideological?

6 'In Britain at least, the old ideological divisions between the parties are obsolete.' Is this true? 